\title{
HARMONISASI PRODUK HUKUM DAERAH DALAM PENYUSUNAN KEBIJAKAN PENANAMAN MODAL (STUDI KASUS DI KABUPATEN BATANG)
}

\author{
Mustamsikin $^{1}$, Yusriyadi $^{2}$
}

\begin{abstract}
Abstrak
Penelitian ini bertujuan untuk mengkaji dan menganalisis kebijakan penanaman modal di Kabupaten Batang berdasarkan Peraturan Daerah tentang Penanaman Modal di Kabupaten Batang, serta menganalisis pentingnya harmonisasi produk hukum daerah penyusunan kebijakan penanaman modal di Kabupaten Batang berdasarkan Peraturan Daerah tentang Penanaman Modal dikaitkan dengan Peraturan Daerah tentang Rencana Tata Ruang Wilayah dan Peraturan Daerah tentang Perlindungan dan Pengelolaan Lingkungan Hidup yang berlaku di Kabupaten Batang. Metode pendekatan yang digunakan dalam penelitian ini adalah metode pendekatan yuridis normatif, yaitu dengan melihat permasalahan dari sudut hukum dalam arti peraturan perundang-undangan dan norma hukum yang berlaku. Hasil penelitian menunjukkan bahwa peran kelembagaan Pemerintah Daerah dalam menghasilkan Peraturan Daerah merupakan salah satu faktor penting dalam meningkatkan penanaman modal atau iklim investasi di daerah. Demikian juga harmonisasi atau sinkronisasi Peraturan Daerah tentang Penanaman Modal dengan produk hukum daerah yang berlaku lainnya mutlak diperlukan agar dalam penerapan kebijakan penanaman modal di daerah bisa terlaksana secara beriringan, efektif serta tidak terjadi ketumpang tindihan aturan.
\end{abstract}

\section{Kata Kunci: Harmonisasi, Produk Hukum Daerah, Penanaman Modal}

\begin{abstract}
The study aims to examine and analyze the investment policy in Batang, as well as to asses and analyze the importance of harmonization of local regulations in investment policy in Batang based on regional regulations on spatial planning and local regulations on environmental protection and management of the apply in Batang. Method of approach used in this study is normative juridical approach. Result of this study indicate that the role of local government institutions in generating local regulations is one important factor in improving the investment or the investment climate in Batang such harmonization of local regulations on the investment product other applicable law is absolutely necessary for the implementation of investment policies in the area can be done in parallel, effectively and avoid overlap rules.
\end{abstract}

Keyword: Harmonization, Local Regulations, Investment

\footnotetext{
${ }^{1}$ Mahasiswa Program Studi Magister Ilmu Hukum UNDIP

${ }^{2}$ Dosen Program Studi Magister Ilmu Hukum UNDIP
} 
A. Latar Belakang

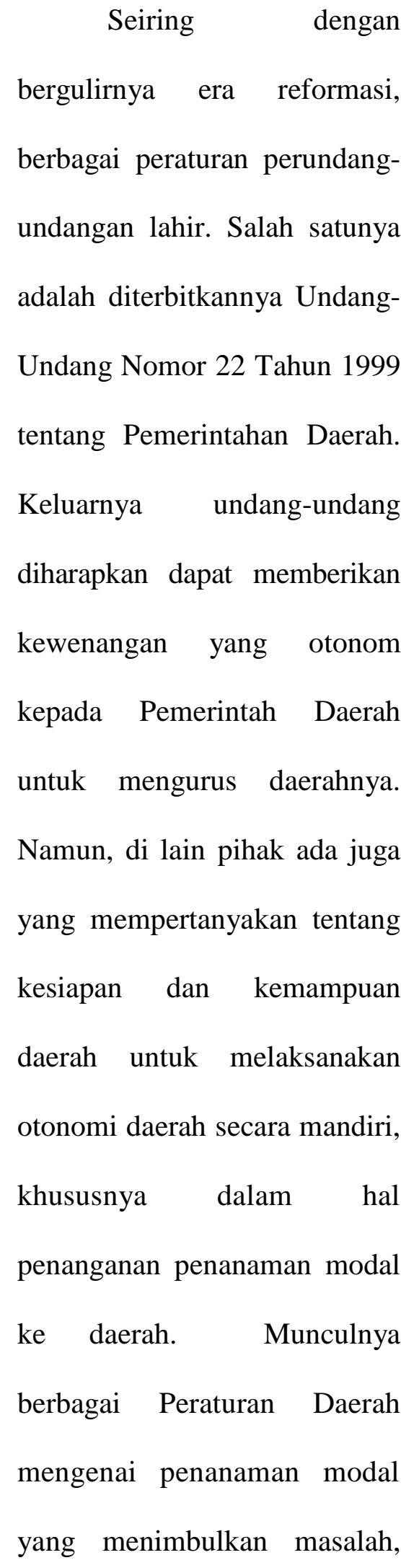

terutama dengan mengabaikan kelestarian lingkungan hidup.

Mencermati berbagai

kendala dalam pelaksanaan

Undang-Undang Nomor 22

Tahun $1999 \quad$ tentang

Pemerintahan Daerah, maka

undang-undang tersebut

dicabut dan diganti dengan

Undang-Undang Nomor 32

Tahun $2004 \quad$ tentang

Pemerintahan Daerah. Adanya

undang-undang ini, diharapkan

daerah mampu menata dan

mengelola potensi-potensi

yang dimilikinya. Berdasarkan

uraian di atas, maka dapat

dirumuskan masalah, yaitu

pertama, bagaimanakah

penyusunan kebijakan

penanaman modal

berdasarkan Peraturan Daerah

tentang Penanaman Modal di

Kabupaten Batang? Kedua, 
bagaimanakah mewujudkan harmonisasi produk hukum daerah dalam penyusunan kebijakan penanaman modal berdasarkan Peraturan Daerah tentang Penanaman Modal di Kabupaten Batang dikaitkan dengan Peraturan Daerah tentang Rencana Tata Ruang Wilayah dan Peraturan Daerah tentang Perlindungan dan Pengelolaan Lingkungan Hidup yang berlaku di Kabupaten Batang?.

\section{B. Metode Penelitian}

Metode pendekatan yang digunakan dalam penelitian ini adalah metode yuridis normatif. Pendekatan ini dilakukan untuk melihat permasalahan dari sudut hukum dalam arti peraturan perundang-undangan dan norma-norma hukum yang berlaku. Data yang digunakan adalah data sekunder, yaitu mencakup dokumen-dokumen resmi, buku-buku hasil penelitian yang berwujud laporan, buku harian dan seterusnya. $^{3}$ Ditunjang dengan data primer, yaitu data yang diperoleh secara langsung dari masyarakat ${ }^{4}$, melalui wawancara dengan subyek penelitian.

\section{Kerangka Teori}

\section{Teori Perundang-undangan}

Maria Farida Indrati Soeprapto, menyatakan bahwa istilah "perundangundangan" (Legislation, wetgeving atau gezetzgebung) mempunyai dua pengertian berbeda, yaitu: 5

${ }^{3}$ Soerjono Soekanto, 1986, Pengantar Penelitian Hukum, Jakarta, Penerbit UI, hlm.12 ${ }^{4} \mathrm{lbid}$

${ }^{5}$ Maria Farida Soeprapto, 2007, IImu Perundangundangan (Jenis, Fungsi, dan Materi Muatan) Jilid 1, Yogyakarta, Kanisius, hlm 3 
a. Perundang-undangan

merupakan

proses

pembentukan/proses

membentuk peraturan-

peraturan negara, baik

ditingkat pusat, maupun

di tingkat daerah;

b. Perundang-undangan

adalah segala peraturan

negara, yang merupakan

hasil pembentukan

peraturan-peraturan, baik

di tingkat Pusat maupun

di tingkat Daerah.

Peraturan perundang-

undangan yang baik harus

memperhatikan asas-asas

pembentukan peraturan

perundang-undangan dan

materi muatan yang tepat.

Asas-asas pembentukan

peraturan perundang-

undangan

telah

dinormatifkan pada Pasal 5 dan penjelasannya dalam

Undang-Undang Nomor 12

Tahun 2011, seperti asas

kejelasan tujuan, asas

kelembagaan atau organ

pembentuk yang tepat; asas

kesesuaian atara jenis dan

materi muatan; dan masih

banyak lagi. Selain itu,

pembentukan peraturan

perundang-undangan juga

harus memperhatikan materi

muatan yang sesuai.

Materi muatan

peraturan perundang-

undangan hanya dapat

dikonsepkan secara umum.

Semakin tinggi kedudukan

suatu peraturan perundang-

undangan, semakin abstrak

dan mendasar materi

muatannya, begitu pun

sebaliknya. Kesemuanya itu

mencerminkan adanya 


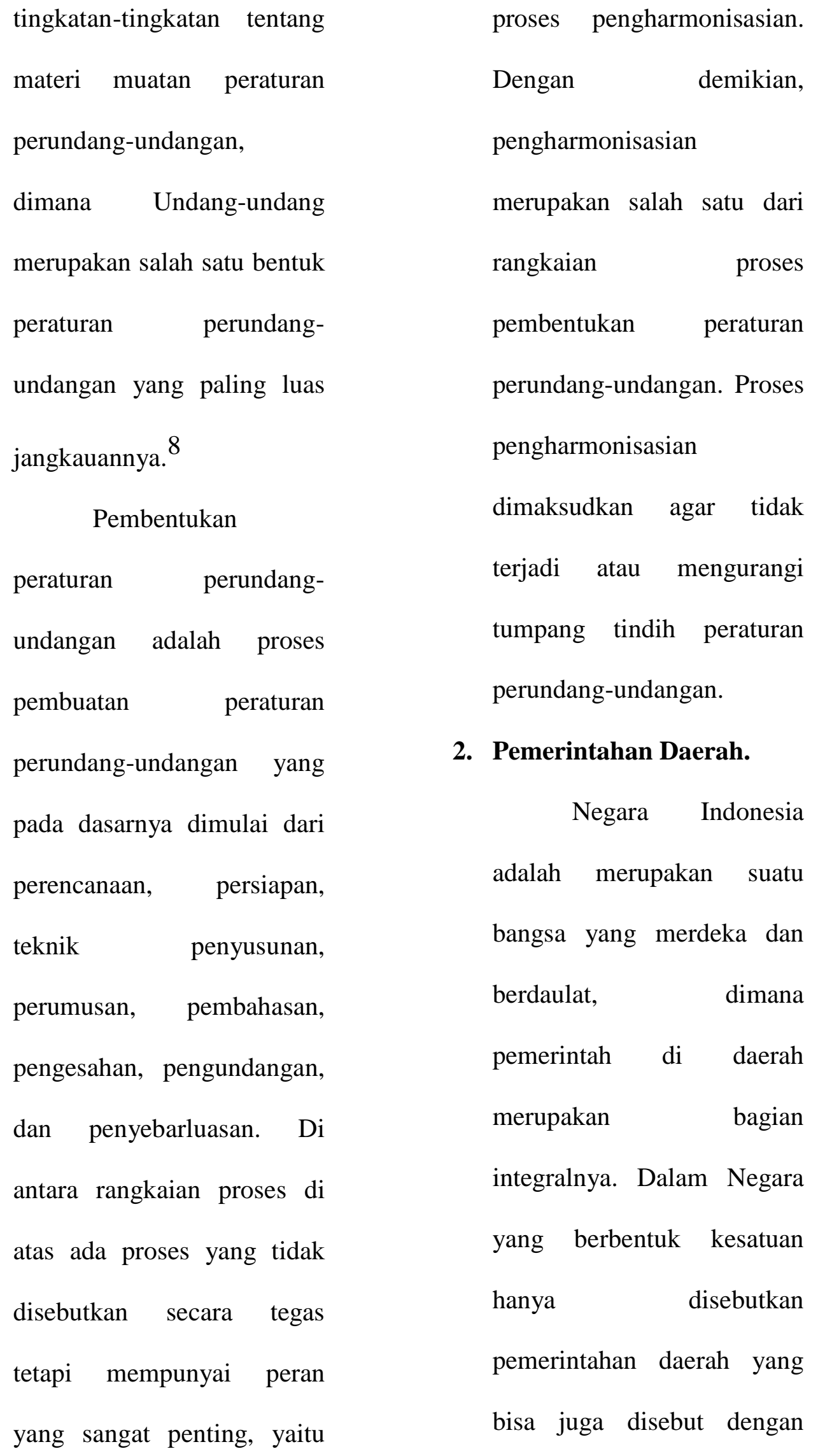




\begin{tabular}{|c|c|}
\hline pemerintah setempat atau & sebagaimana \\
\hline pemerintah lokal (local & dimaksud \\
\hline government). Dasar hukum & undang \\
\hline dari adanya Pemerintah & Indonesia \\
\hline Daerah diatur pada Pasal 18 & Pembagian \\
\hline ayat (1) UUD NRI Tahun & pemerintahan di Indonesia \\
\hline 1945. & diatur dalam Pasal 10-Pasal \\
\hline Pengertian & 18 Undang-Undang Nomor \\
\hline Pemerintah Daerah diatur & 32 Tahun \\
\hline pada Pasal 1 angka & Pemerintahan \\
\hline Undang-Undang Nomor 32 & Secara singkat, pembagian \\
\hline tentang & urusan pemerintahan \\
\hline Pemerintahan Daerah, yang & Indonesia terbagi dalam 3 \\
\hline menyatakan: "Pemerintahan & (tiga) \\
\hline Daerah & desentralisasi, dekonsentrasi \\
\hline penyelenggaraan & dan tugas pembantuan. \\
\hline pemerintahan & Sebagai konsekuensi \\
\hline Pemerintah Daerah dan & dari hak mengatur \\
\hline menurut & mengurus rumah tangga atas \\
\hline otonomi & inisiatif \\
\hline pembantuan dengan prinsip & kepada pemerintah \\
\hline seluas-luasnya & yang berhak mengatur dan \\
\hline dalam sistem dan prinsip & mengurus rumah \\
\hline Negara Kesatuan Republik & dilengkapi \\
\hline
\end{tabular}


dengan alat perlengkapan

daerah yang dapat

mengeluarkan peraturan-

peraturannya, yakni

Peraturan Daerah (Perda).

Keberadaan Perda

merupakan conditio sine

quanon

(syarat

absolut/syarat mutlak) dalam

rangka melaksanakan

kewenangan otonomi

tersebut. Perda harus

dijadikan pedoman bagi

Pemerintah Daerah dalam

melaksanakan urusan-urusan

di daerah. Di samping itu,

perda juga harus dapat

memberikan perlindungan

hukum bagi rakyat di

daerah. ${ }^{6}$

\section{Tinjauan tentang Investasi}

Usaha.

Investasi adalah

pendayagunaan sumberdaya

6 Ibid, hlm. 85 hari ini untuk mendapatkan

keuntungan di masa depan. ${ }^{7}$

Investasi bukanlah produk

melainkan proses, yang

berarti menunjukkan adanya

upaya mengubah sesuatu

menjadi sesuatu yang lain,

yang mempunyai nilai guna

lebih tinggi. Di negara-

negara maju, pertumbuhan

ekonomi lebih banyak

digerakkan oleh pelaku

bisnis, sehingga investasi

seringkali bermakna

investasi usaha. Investasi

usaha merupakan suatu

proses atau kegiatan dimana

seorang atau istitusi

membelanjakan anggarannya

untuk mengembangkan suatu

suatu kegiatan usaha yang

mendatangkan laba

7 Ahmad Syamsuddin dan Marsuki, 2007, Iklim Investasi Daerah (Buku Panduan untuk Membangun Iklim Investasi di Daerah), Cetakan Pertama, Konras-Adenuer-Stiftung e.V, hlm 3 
finansial. ${ }^{8}$ Namun demikian, terdapat investasi yang bukan merupakan investasi usaha. Investasi seperti ini menghasilkan laba nonfinansial dalam bentuk kemanfaatan bagi

pelaksananya, $\quad$ yang kemudian berdampak secara ekonomi. Investasi nonbisnis sebenarnya bersifat mempersiapkan investasi bisnis.

\section{Hasil dan Pembahasan}

1. Kebijakan Penanaman

Modal di Kabupaten

\section{Batang}

Ditetapkannya

Peraturan Daerah Nomor 2

Tahun $2013 \quad$ tentang

Penanaman Modal di

Kabupaten Batang

diharapkan membawa semangat pelayanan publik yang lebih baik lagi. Selain itu, juga sebagai upaya untuk memberikan jaminan hukum yang lebih pasti bagi para investor. Dengan kata lain, Pembuatan Peraturan Daerah tentang Penanaman Modal tersebut dengan berbagai sistem yang menyertainya, seperti pelayanan administrasi satu pintu dan pemberian kemudahan maupun insentif lainnya akan membawa perubahan terhadap iklim investasi di Kabupaten Batang, sehingga diharapkan Batang akan semakin menggeliat dan ramai dalam kegiatan penanaman modal. Perda Penanaman Modal di Kabupaten Batang dimaksudkan sebagai salah

8 Ibid, hlm 4 


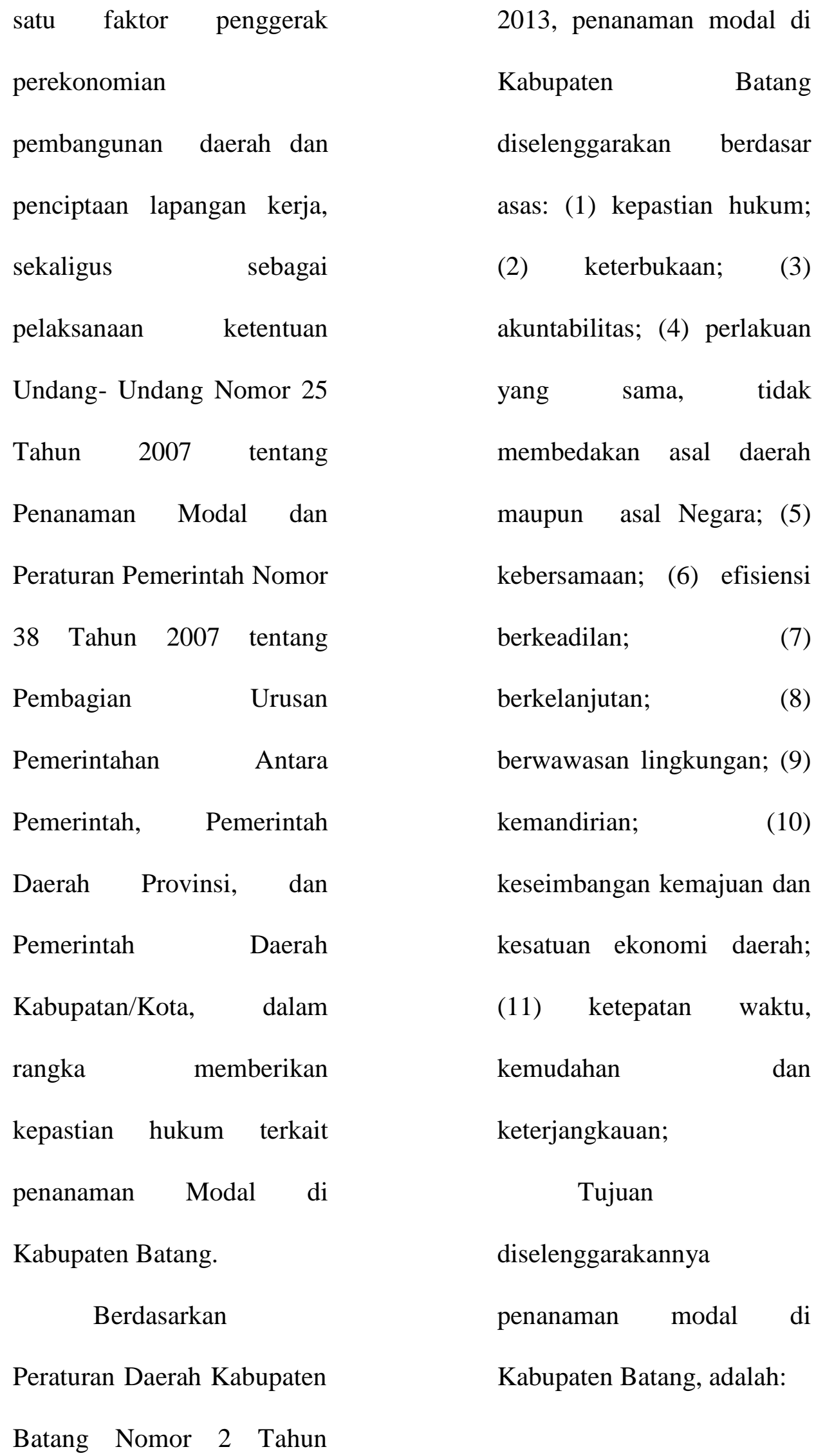


a. meningkatkan

pertumbuhan ekonomi

daerah;

b. menciptakan lapangan

kerja;

c. meningkatkan

pembangunan ekonomi

berkelanjutan dan

berwawasan lingkungan

yang berkelanjutan

dengan mengoptimalkan

kontribusi sektor swasta

melalui CSR;

d. Mendukung dan

menumbuhkembangkan

kemampuan daerah

untuk lebih mampu

bersaing ditingkat

regional, nasional dan

internasional

berdasarkan keunggulan

kompetitif daerah

terutama kontribusi

daerah dan mengembangkan serta

memperkuat industi dan

perdagangan daerah;

e. Meningkatkan

pendapatan daerah untuk

memberikan kontribusi

yang sebesar-besarnya

bagi perekonomian

daerah dan

mengembangkan serta

memperkuat industri dan

perdagangan daerah;

f. Meningkatkan

kemampuan daya saing

dunia usaha daerah;

g. Meningkatkan kapasitas

dan kemampuan

teknologi daerah;

h. Mendorong

pengembangan ekonomi

kerakyatan;

i. Meningkatkan dan

mengembangkan

ekonomi potensial 


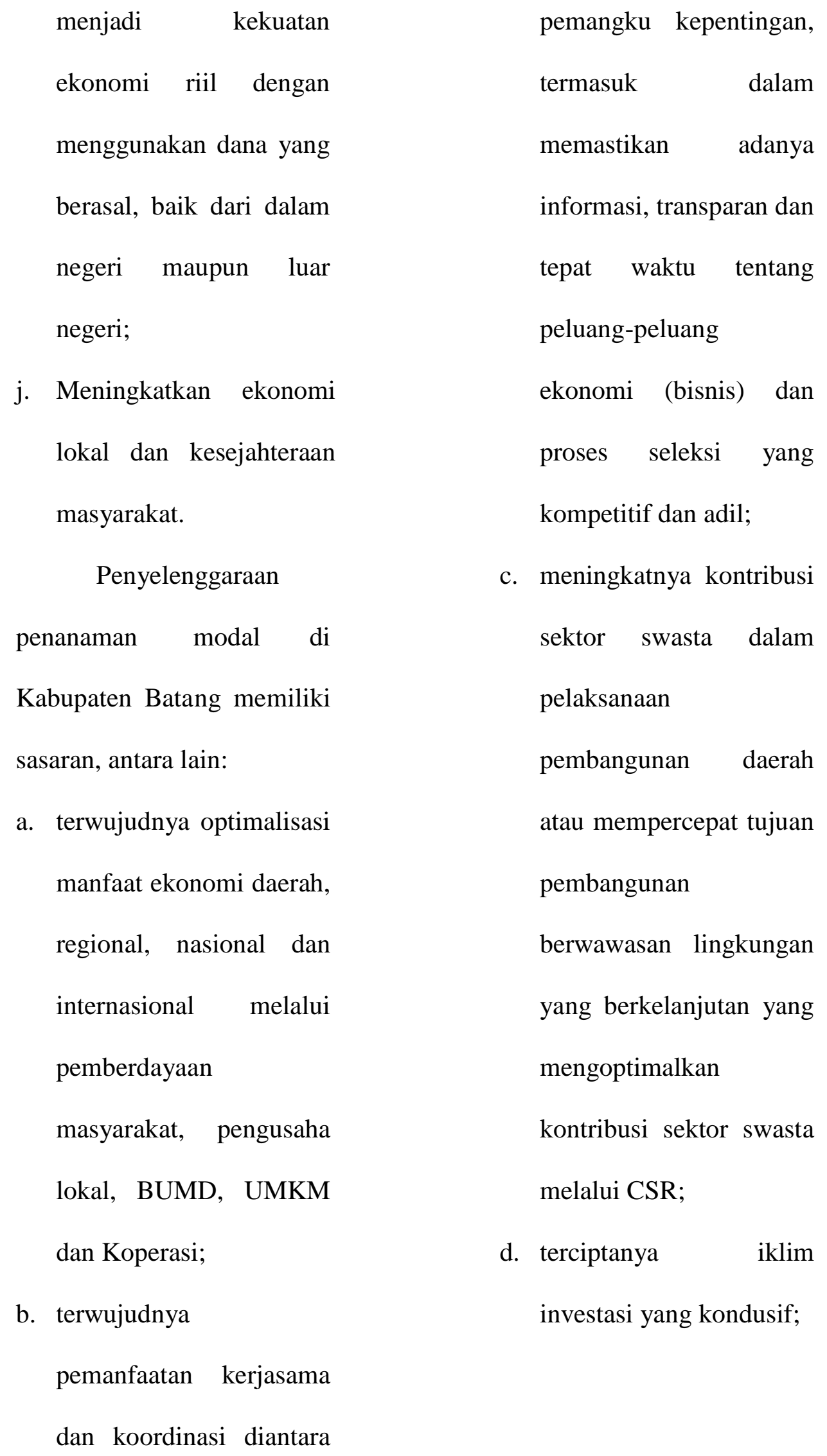


e. meningkatnya sarana prasarana pendukung penanaman modal;

f. meningkatnya sumberdaya manusia;

g. meningkatnya jumlah penanam modal dan realisasi penanaman modal;

h. meningkatnya kreativitas dan sistim inovasi daerah.

\section{Harmonisasi Produk Hukum} Daerah dalam Penyusunan Kebijakan Penanaman Modal dengan Peraturan Daerah tentang Rencana Tata Ruang Wilayah dan Peraturan Daerah tentang Perlindungan dan Pengelolaan Lingkungan Hidup yang berlaku di Kabupaten Batang

a. Harmonisasi

Produk

\section{Hukum Daerah dalam}

Penyusunan Kebijakan

Penanaman Modal dengan

Peraturan Daerah

Kabupaten Batang

Nomor 7 Tahun 2011

tentang Rencana Tata

Ruang dan Tata Wilayah

Kabupaten Batang

Perda Kabupaten

Batang Nomor 7 Tahun

2011 tentang Rencana Tata

Ruang dan Tata Wilayah

Kabupaten Batang Tahun

2011-2031 diantaranya

memuat tentang tujuan

Penataan Ruang dan

Wilayah, yaitu untuk

meningkatkan investasi

daerah yang bertumpu pada

sektor pertanian. Ketentuan

terkait arahan investasi yang

bertumpu pada sektor

pertanian juga sebaiknya

diatur secara rinci dalam 


\begin{tabular}{|c|c|}
\hline penyusunan & Pengelolaan \\
\hline investasi. Di samping itu, & Hidup \\
\hline terkait penentuan zona dan & Dalam \\
\hline lokasi investasi juga tidak & ayat (2) Peraturan Daerah \\
\hline boleh bertentangan dengan & Kabupaten Batang Nomor \\
\hline arahan tata ruang dan & tentang \\
\hline Permasalahan & Penanaman \\
\hline yang muncul kemudian & disebutkan bahwa salah satu \\
\hline adalah banyaknya investasi & tanggungjawab \\
\hline yang masuk ke daerah, & Modal adalah \\
\hline namun banyak yang usahanya & kelestarian lingkungan. Pasal \\
\hline tidak bertumpu pada sektor & tersebut tidak merujukkan \\
\hline pertanian, tetapi terkadang & secara $\quad$ spesifik \\
\hline pertanian diubah & pengaturan \\
\hline menjadi lahan industri/pabrik. & lingkungan hidup yang \\
\hline Harmonisasi & termasuk \\
\hline Hukum Daerah dalam & menyangkut \\
\hline Penyusunan & tanggungjawab \\
\hline Penanaman Modal dengan & terhadap \\
\hline Peraturan & sebagaimana \\
\hline Kabupaten Batang Nomor & termaktub dalam pasal-pasal \\
\hline 16 Tahun 2010 tentang & di Perda Kabupaten Batang \\
\hline Perlindungan & Nomor \\
\hline
\end{tabular}


Pengelolaan Lingkungan

Hidup.

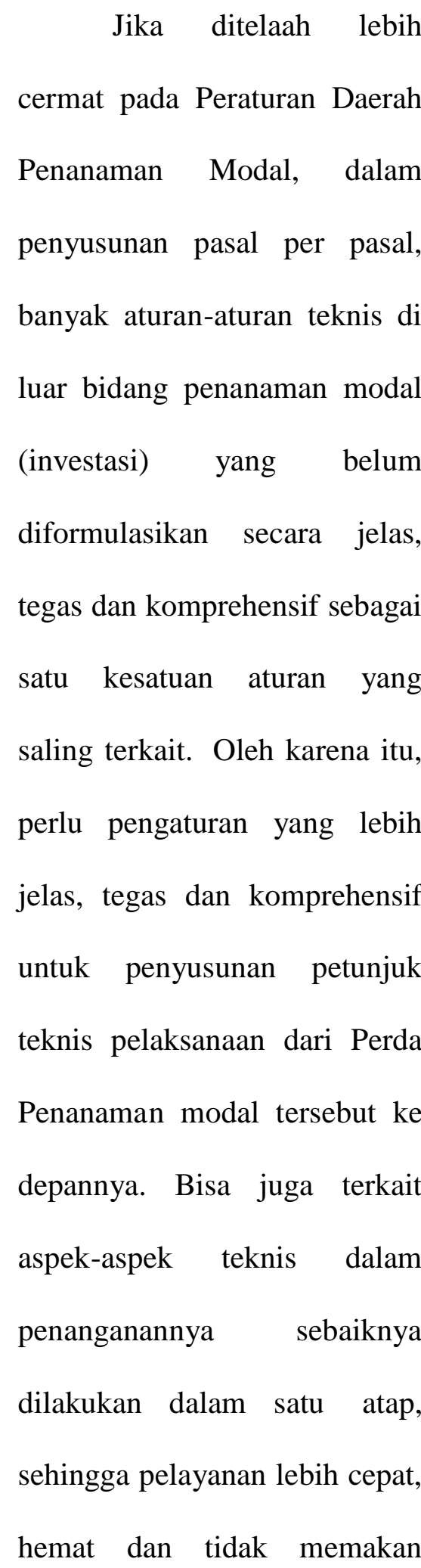

waktu yang lama. Di samping itu, pelayanan satu atap tersebut bisa meminimalisir risiko pelanggaran administrasi maupun ketidaktertiban proses pengadministrasian yang bisa berimplikasi hukum.

\section{E. Simpulan}

Penanaman modal di Kabupaten Batang diatur dalam Peraturan Daerah Kabupaten Batang Nomor 2 Tahun 2013 tentang Penanaman Modal. Perda ini sebagai pelaksanaan ketentuan Undang-Undang Nomor 25 Tahun 2007 tentang Penanaman Modal dan Peraturan Pemerintah Nomor 38 Tahun 2007 tentang Pembagian Urusan Pemerintahan Antara Pemerintah, Pemerintah Daerah Provinsi, dan Pemerintah Daerah Kabupatan/Kota, dalam 
rangka memberikan kepastian

hukum terkait penanaman

Modal di Kabupaten Batang.

Perda penanaman modal ini seharusnya sejalan dengan

peraturan perundang-undangan

yang terkait dengan lingkungan

hidup.

Dalam

Perda

Kabupaten Batang tentang

Rencana Tata Ruang Wilayah

disebutkan bahwa penentuan

zonasi dan lokasi investasi

ataupun industri tidak boleh

bertentangan dengan arahan

tata ruang dan wilayahnya

dan harus bertumpu pada sektor

pertanian.

Namun,

kenyataannya banyak usaha

yang tidak bertumpu pada

sektor pertanian. Dalam Perda

tentang Penanaman Modal

disebutkan bahwa salah satu

tanggungjawab Penanam
Modal adalah menjaga

kelestarian lingkungan. Pasal

tersebut tidak mengatur secara

spesifik terkait pengaturan

bidang lingkungan hidup,

termasuk menyangkut

kewajiban ataupun

tanggungjawab dunia usaha

terhadap lingkungan,

sebagaimana termaktub pada

pasal-pasal dalam Perda

tentang Perlindungan dan

Pengelolaan Lingkungan Hidup

di Kabupaten Batang.

\section{Daftar Pustaka}

Farida Soeprapto, Maria, 2007, Ilmu Perundang-undangan (Jenis, Fungsi, dan Materi Muatan), Jilid 1, Yogyakarta: Kanisius

Soekanto, Soerjono, 1986, Pengantar Penelitian Hukum, Jakarta: Penerbit UI

Syamsuddin, Ahmad dan Marsuki, 2007, Iklim Investasi Daerah (Buku Panduan untuk Membangun Iklim Investasi di Daerah), Cetakan Pertama, Konras-AdenuerStiftung e.V 
Peraturan Perundang-undangan:

Undang-Undang Nomor 32 Tahun

2004 tentang Pemerintahan

Daerah

Undang-Undang Nomor 25 Tahun

2007 tentang Penanaman

Modal

Undang-Undang Nomor 26 Tahun

2007 tentang Penataan Ruang

Undang-Undang Nomor 32 Tahun 2009 tentang Perlindungan dan Pengelolaan Lingkungan Hidup

Undang-Undang Nomor 12 Tahun 2011 tentang Pembentukan Peraturan Perundangundangan

Peraturan Pemerintah Nomor 38 Tahun 2007 tentang Pembagian Urusan Pemerintahan Antara Pemerintah, Pemerintah Daerah Provinsi dan Pemerintah Daerah Kabupaten/Kota

Peraturan Pemerintah Nomor 26 Tahun 2008 tentang Rencana Tata Ruang Wilayah Nasional

Peraturan Menteri Dalam Negeri Nomor 54 Tahun 2009 tentang Tata Naskah Dinas di Lingkungan Pemerintah Daerah
Peraturan Daerah Kabupaten Batang Nomor 7 Tahun 2011 tentang Rencana Tata Ruang Wilayah Kabupaten Batang Tahun 2011-2013

Peraturan Daerah Kabupaten Batang Nomor 16 Tahun 2010 tentang Perlindungan dan Pengelolaan Lingkungan Hidup

Peraturan Daerah Kabupaten Batang Nomor 2 Tahun 2013 tentang Penanaman Modal di Kabupaten Batang

$$
\begin{array}{ccc}
\text { Peraturan Bupati Batang } & \text { Nomor } \\
59 \text { Tahun 2012 } & \text { tentang } \\
\text { Tugas Pokok, } & \text { Fungsi, } \\
\text { Uraian Tugas dan Tata Kerja } \\
\text { Badan Penanaman Modal } \\
\text { dan Perijinan Terpadu } \\
\text { Kabupaten Batang }
\end{array}
$$

Peraturan Bupati Batang Nomor 82 Tahun 2012 tentang Pendelegasian Wewenang Pemberian Perizinan dan Non Perizinan di Bidang Penanaman Modal kepada Kepala Badan Penanaman Modal dan Perizinan Terpadu Kabupaten Batang. 